\title{
Iseljavanje iz Hrvatske od 1900. do 2001.: demografske posljedice stoljetnog procesa
}

\author{
DOI: $10.11567 / \mathrm{met} .30 .3 .6$ \\ UDK: 314.743:314.8](497.5)"1900/2001" \\ Pregledni rad \\ Primljeno: 17.5.2014. \\ Prihvaćeno: $28 \cdot 10.2014$.
}

\section{Ivo Nejašmić}

Učiteljski fakultet, Sveučilište u Zagrebu, Zagreb

ivo.nejasmic@ufzg.hr

\begin{abstract}
SAŽETAK
U razmatranom se razdoblju, 1900. - 2001., s prostora današnje Republike Hrvatske iselilo oko 2,3 milijuna osoba. Doseljavanje je ublažilo odljev »ljudskoga kapitala«; nadomjestilo je gotovo polovinu ukupnoga iseljenoga kontingenta. Migracijski »bilančni manjak « odnio je 33,4\% prosječnog broja stanovnika, ili 52\% ukupne prirodne promjene (prirasta). Malo je zemalja koje su imale tako značajni gubitak stanovništva u vanjskoj migraciji. Ukupni populacijski gubici Hrvatske u razmatranom razdoblju iznose oko 1,89 milijuna osoba, a pojedine kategorije imaju sljedeći udio: negativna bilanca vanjske migracije $63,3 \%$, ratni gubici $32,7 \%$ i epidemije $4,0 \%$. Da nije bilo vanjske migracije (dakle u hipotetično »zatvorenoj populaciji«), Hrvatska bi 2001. imala najmanje 6,22 milijuna stanovnika, ili 40,1\% više od popisanoga broja. Dugoročni (odgođeni) učinci iseljavanja također su došli do punog izražaja. Iseljavanjem najvitalnijih dobnih skupina došlo je do sužavanja fertilnih kohorti te posljedično do smanjenja rađanja i povećanja stope smrtnosti. Početkom devedesetih zabilježena je negativna stopa prirodne promjene. Na biološku (prirodnu) depopulaciju djelovalo je više čimbenika, no na prvome je mjestu iseljavanje. Neprekidno i snažno iseljavanje, odnosno negativna migracijska bilanca, jedan je od glavnih razloga što se Hrvatska našla u skupini deset europskih zemalja s najstarijom populacijom. Nakon 19. stoljeća, u kojem je populacija Hrvatske udvostručena, i 20. stoljeća, u kojem je zabilježen slabi rast (40,4\%), 21. stoljeće obilježit će depopulacija. Među mnogim čimbenicima koji utječu na takvu demografsku perspektivu Hrvatske važnu ulogu ima izrazito negativna bilanca vanjske migracije iz analiziranoga stoljetnog razdoblja.
\end{abstract}

KLJUČNE RIJEČI: iseljavanje, migracijska bilanca, gubici stanovništva, demografske posljedice iseljavanja, Hrvatska

\section{UVOD}

Prema relevantnim demografsko-statističkim pokazateljima, stanovništvo Hrvatske obilježavaju smanjujući fertilitet, negativni prirodni prirast (prirodna depopulacija), emigracijska depopulacija, ukupna depopulacija i starenje stanovništva. Takva populacijska slika Hrvatske izraz je demo- 
grafskih kretanja i društvenih zbivanja kroz stoljeća, ali su u njezinu oblikovanju glavnu ulogu imale prilike tijekom 20. stoljeća, sa sve naglašenijom akceleracijom prema današnjici. To je razdoblje bremenito društvenim, političkim, vojnim i gospodarskim zbivanjima i prijelomnim promjenama. U kolopletu su opći čimbenici, ali i mnogi posebni, koji, povezano djelujući, različito pridonose oblikovanju kompleksne slike demografske stvarnosti. Jedan od takvih općih čimbenika, koji ima i posebne »lokalne « značajke, jest vanjska migracija, odnosno emigracija kao izlazna sastavnica tog procesa i negativna strana (»pasiva«) ukupne demografske bilance.

Postavlja se pitanje: zašto se ljudi sele? Ili: zašto se jedni sele, a drugi ne? Dio odgovora nedvojbeno proistječe iz neravnomjerna društveno-gospodarskog razvoja i njegove vremenske i prostorne dimenzije. Dokazano je u brojnim istraživanjima da su gospodarski čimbenici bitna determinanta seobe stanovništva između dva područja. ${ }^{1}$ Razumije se, time se ne zanemaruju drugi čimbenici (koji su katkada prevladavajući): prirodno-geografski, društveni, kulturni, politički i drugi. Ostatak odgovora valja potražiti prije svega $\mathrm{u}$ informacijskoj i prometnoj dostupnosti. Budući da je migracija svojevrsni inovacijski proces, nema sumnje da je raspolaganje informacijom o »vanjskom svijetu« preduvjet (pretpostavka) migriranja. Dostupnost transportnih sredstava i tehničko-prometna revolucija utjecale su na porast sklonosti traženju zarade i boljeg života u tuđini. Uloga informacije i dostupnosti prometnih sredstava u razmatranom procesu navodi na zaključak da emigracija nije uvijek najveća iz najsiromašnijih (perifernih) krajeva, kako se obično misli. U ranoj fazi iseljavanja odlaze nešto imućniji, sposobniji i spremniji na rizik (Nejašmić, 1991). Tko će se pak seliti, umnogome ovisi o motivima, preferencijama i mogućnostima pojedinca ili skupine, dakle o individualnim determinantama. Valja istaknuti da svi dijelovi određene zemlje $u$ pravilu ne sudjeluju jednako $u$ »izvozu« stanovništva. U područjima u kojima se odvijala intenzivnije i s više pojavnih oblika emigracija je ostavila teže demografske i druge posljedice.

Kao sastavnica ukupnoga kretanja stanovništva migracija djeluje: a) na veličinu ukupnog stanovništva i njegov prostorni razmještaj, b) na sastavnice prirodnoga kretanja (rodnost i smrtnost) i c) na sastav stanovništva (demografski, društveno-gospodarski i kulturno-antropološki) (Nejašmić, 2005). Kakvi će biti učinci iseljavanja na demografske prilike i procese, ovi-

Sve do pred kraj 19. stoljeća vladalo je mišljenje da migracija ne podliježe nikakvim pravilima ili zakonitostima. Prvi je tome doskočio E. G. Ravenstein, koji je 1885. predočio rezultate svojih istraživanja. Njegovi se nalazi (postavke), tj. »zakoni migracije«, mogu predočiti u jedanaest točaka, a jedna od njih tvrdi da su glavni uzroci migracije ekonomske prirode (prema Wertheimer-Baletić, 1999: 290). 
si o kvantitativnim i kvalitativnim (strukturnim) značajkama iseljeničkoga kontingenta. Krajnji učinak na ukupni broj stanovnika jasan je: iseljavanje je negativna komponenta ukupnoga kretanja i uzrokuje, uz ostale nepromijenjene uvjete, smanjenje broja stanovnika. Budući da stanovništvo koje se seli ima određena obilježja, a istraživanja su pokazala da u tome sudjeluju pretežito mlađe skupine, to seljenje utječe i na promjene sastava stanovništva, kako u mjestu podrijetla tako i u mjestu doseljenja. U polazištu nepovoljno djeluje na strukturna obilježja stanovništva, posebice na sastav prema dobi (pospješuje starenje), a time i na sastavnice prirodnoga kretanja.

Uz to valja istaknuti da emigracija ima dva vremenska učinka: a) trenutačni, koji odmah smanjuje broj stanovnika, i b) dugoročni (odgođeni), koji proistječe iz trenutačnoga, a »očituje se $u$ tome da stanovništvo koje napušta rodni kraj, istodobno 'odnosi' sa sobom buduća rođenja, smrti, sklapanja i razvode brakova koje bi to stanovništvo doživjelo u svom životnom vijeku u mjestu podrijetla da se nije selilo« (Wertheimer-Baletić, 1999: 284). Prema tome, emigracijom inducirano smanjenje fertilnih kohorti dovodi u području podrijetla migranata do smanjenja mase rađanja, ali i do povećanja stope smrtnosti jer se seli uglavnom mlađi dio stanovništva, koji je ujedno manje podložan riziku od smrti. Rezultat toga jest redukcija prirodnog prirasta, što u konačnici može dovesti do prirodne depopulacije. Ipak, valja reći da u ranoj fazi emigracija može kratkotrajno imati i koristan učinak, odnosno javlja se »kao demografski regulator s blagotvornim učinkom; u Starom svijetu i agrarno-ruralnim društvima ona smanjuje populacijski pritisak « (Woods, 1982: 131).

Opće je poznato da (e)migracija ima s općedruštvenoga, populacijskoga i etničkoga gledišta za svaku zemlju iznimnu važnost. U ovom ćemo radu razmotriti slučaj Hrvatske u razdoblju 1900. - 2001. polazeći od njezina današnjega teritorijalnog obuhvata. Težište je na spoznaji značajki stoljetnog iseljavanja (dinamika, pravci, obujam) i njegova utjecaja na glavne demografske promjene u Hrvatskoj. Svrha je ovog rada dati skroman doprinos općoj spoznaji populacijskih procesa, a prije svega pridonijeti fondu znanja o demografskom razvoju nacionalnog prostora. No to ćemo ostaviti stranicama koje slijede, a kao moto istaknuti zaključak J. Gele (1987: 198), koji je, istražujući dvjestogodišnji demografski razvoj na tlu Hrvatske, napisao: »Vrlo malo je područja i zemalja u svijetu koje su imale tako značajan gubitak stanovništva zbog nepovoljnih migracijskih tokova«. 


\section{METODOLOŠKE NAZNAKE}

U proučavanju demografskih promjena $\mathrm{u}$ stoljetnom razdoblju na tlu Hrvatske javlja se nekoliko metodoloških teškoća. Recimo odmah da je na pitanje o broju iseljenih osoba u tako dugom razdoblju teško precizno odgovoriti. U mnogim zemljama istraživači imaju teškoća s kakvoćom statističke građe o migracijama. U Hrvatskoj je to posebice istaknut problem; razlog je u nedostatku pouzdanih, a za neke krajeve i razdoblja bilo kakvih podataka. ${ }^{2}$ Vanjska je migracija uglavnom širom svijeta najslabije praćeni dio demografske statistike, iako za taj oblik prostorne pokretljivosti vlada veliki interes struke i politike. Očigledno postoji raskorak između interesa i mogućnosti. Kada je riječ o prekograničnoj migraciji, »zapravo je glavni problem evidencija odseljenika [...] Naime, u modernim demokratskim zemljama svaka odrasla osoba (ili obitelj) može otputovati iz zemlje prebivališta, a da za to ne mora tražiti odobrenje ili svoj odlazak izvan matične države bilo kome 'prijaviti'. A odlazak, kratkotrajan i privremen može prerasti u trajan - doživotan« (Gelo, Akrap i Čipin, 2005: 67). Stoga je u slučaju kvantificiranja migracijskih tokova riječ o više ili manje utemeljenoj procjeni.

U nedostatku točnih podataka nužnih za utvrđivanje bilance migracijskih tokova demografski analitičari izračunavaju migracijski saldo. To je učinjeno i u ovom radu. Riječ je o komparativnoj ili vitalnostatističkoj metodi istraživanja migracije koja se temelji na ukupnom kretanju stanovništva i prirodnoj promjeni između dvaju popisa (Nejašmić, 2005). Migracijski saldo $(S)$ dobije iz izraza:

$$
S=P_{2}-\left(P_{1}+P p\right)
$$

gdje je $P$ broj stanovnika određenog područja na kraju promatranog razdoblja, $P_{1}^{2}$ broj stanovnika početkom razdoblja, a $P p$ prirodna promjena (razlika broja živorođenih i umrlih) u promatranom razdoblju. Dakle rabe se podaci popisâ stanovništva i demografske (vitalne) statistike. Dobije se razlika između stvarno popisanog broja stanovnika $\left(P_{2}\right)$ i (očekivanog) broja stanovnika koji bi bio popisan da je stanovništvo između dvaju popisa brojčano raslo (ili se smanjivalo) samo na osnovi prirodne promjene $\left(P_{1}+P p\right)$. Rezultat znači razliku između broja doseljenih i iseljenih. Pozitivni saldo pokazuje koliko se osoba više doselilo nego što ih se odselilo, a negativni koliko ih se više iselilo nego doselilo.

\footnotetext{
Hrvatska još uvijek nema upisnik (registar) stanovništva, koji je, kao tekuća baza podata-
} ka, najtočniji izvor podataka o migraciji. 
Jedna je od teškoća u demografskoj analizi usporedivost/neusporedivost ukupnog broja stanovnika. Od 1971., otkako se »službeno priznaje « postojanje brojne »radne $\mathrm{i}$ »privremene « emigracije $u$ inozemstvu, uz popisano stanovništvo u zemlji (u mjestu prebivališta) u ukupno stanovništvo upisani su svi koje se moglo popisati u inozemstvu ili za koje se moglo preko rodbine utvrditi da prebivaju u inozemstvu. Metodologija popisa stanovništva 2001. razlikuje se od metodologije prethodnih popisa. U tom je popisu prihvaćen koncept »uobičajenog mjesta stanovanja (place of usual residence) $\mathrm{s}$ vremenskim ograničenjem odsutnosti do dvanaest mjeseci (prema Preporukama EEC/EUROSTAT-a i UNSTAT-a). No u konačnici su neke sastavnice koncepcije de iure ipak ostale, npr. kontingent građana $u$ inozemstvu »koji održavaju čvršće veze s domovinom « (tj. u mjesto stalnog stanovanja vraćaju se sezonski i mjesečno). Popisom je tako obuhvaćen i dio građana Hrvatske koji su na radu ili boravku u inozemstvu duže od dvanaest mjeseci. Znači da Preporuke nisu dosljedno provedene, a obuhvat te skupine bio je podložan subjektivnim ocjenama (kriteriji nisu bili jasno definirani). Razlike u metodologiji »administrativno « utječu posebice na usporedivost podataka popisa 1991. i 2001. Naime obuhvat »inozemaca« bio je različit, ali ni u jednom od ta dva slučaja nije bio ni približno cjelovit. Stoga se, uz određene rezerve, ipak može uspoređivati ukupni broj stanovnika 1991. i 2001. Unatoč nedostacima (njihovo otklanjanje bilo bi vrlo složeno i podložno metodološkim spekulacijama) analiza kretanja ukupnog broja stanovnika 1900. - 2001. temelji se na službenim popisnim podacima.

\section{ISELJAVANJE -OSNOVNE ZNAČAJKE DUGOTRAJNOG PROCESA}

Gruba periodizacija razmatranog razdoblja, koju bitno određuju krupna društveno-gospodarska i politička zbivanja, ima tri glavna podrazdoblja: a) od početka stoljeća do kraja Drugoga svjetskog rata - točnije, prvoga poslijeratnog popisa stanovništva (1900. - 1948.), b) od Drugoga svjetskoga rata do raspada druge Jugoslavije (1948. - 1991.) i c) desetljeće samostalne Republike Hrvatske (1991. - 2001.).

\section{Razdoblje 1900. - 1948.}

Početkom 20. stoljeća iseljavanje s prostora današnjega hrvatskog državnog teritorija zbivalo se u sklopu Velike migracije u prekomorske zemlje. Taj migracijski tok odveo je mahom dio viškova europskoga poljoprivrednog stanovništva u Sjevernu i Južnu Ameriku, Južnu Afriku, Australiju i Novi 
Zeland. Procjenjuje se da je prekomorska migracija zahvatila oko 55 do 65 milijuna Europljana od 1820. do 1930. (Jones, 1990). Brojni čimbenici, uglavnom ekonomske prirode (agrarna kriza, slaba mogućnost zarade izvan sela itd.), poticali su Europljane na odlazak, a s druge strane privlačile su ih brojne mogućnosti koje je pružao razvoj zemalja Novog svijeta, poglavito SAD-a.

I u slučaju Hrvatske iseljavalo se uglavnom poljoprivredno stanovništvo, što je sukladno tadašnjoj gospodarskoj strukturi (Nejašmić, 1991). Valja istaknuti da su središta političke moći bila izvan hrvatskih zemalja, što je uvelike utjecalo na marginalizaciju i društveno-gospodarsko zaostajanje. Industrijalizacija je bila slaba, posve nedostatna za prihvaćanje osiromašene seljačke mase koja je napuštala sela u potrazi za bilo kakvom zaradom. U takvim se okolnostima iseljavanje pokazalo jedinim rješenjem. Mnogi odlaze u prekomorske zemlje s namjerom da nešto steknu i vrate se u zavičaj. No u većini slučajeva to je značilo trajno napuštanje domovine (Antić, 1985). Do Prvoga svjetskog rata prekomorsko je iseljavanje poprimilo masovno obilježje.

Iseljavanje je bilo uvjetovano i demografskim pritiskom. Početkom osamdesetih godina 19. stoljeća na tlu Hrvatske počinje demografska tranzicija. Opća stopa mortaliteta pada ispod $30 \%$, a to je uz zadržavanje visoke rodnosti povećalo pozitivnu prirodnu promjenu (prirast) stanovništva. ${ }^{3}$ Time se povećala ionako velika agrarna prenapučenost, pojava koja je bila jedna od glavnih značajki hrvatskog rurisa s iznimkom Slavonije (Bićanić, 1940). Jednostavno rečeno, namnožilo se puno gladnih usta koja je trebalo hraniti. Nema dvojbe da je ta činjenica dodatno poticala potragu za zaradom i odlazak u »obećanu zemlju Ameriku«.

Kod iseljavanja je do izražaja došao i samogenerirajući čimbenik: »Naime, kada jednom 'pusti korijenje', proces se nastavlja čak i onda kada prestanu djelovati inicijalni uzroci; odvija se kanalima rodbinstva, prijateljstva i susjedstva, stvarajući tako tradiciju iseljavanja « (Nejašmić, 1991: 94). Tako u mnogim krajevima odlazak mladih i zdravih snaga postaje »normalna « stvar, koja se sama po sebi razumije.

U kolopletu čimbenika iseljavanja do Prvoga svjetskog rata, uza spomenute opće ističu se i posebni čimbenici koji su značajno utjecali na dinamiku i obujam iseljavanja iz pojedinih hrvatskih krajeva. Takvu ulogu u Banskoj Hrvatskoj, po nekim istraživačima, imali su raspad kućnih zadruga i zaduženost seljakâ (Pavličević, 1984). U Dalmaciji su, osim opće zaostalosti,

Od 1899. do 1914. prosječna godišnja prirodna promjena (prirast) iznosila je 13,5\%o, najviše u hrvatskoj povijesti (Gelo, 1987). 
glavni čimbenici iseljavanja bili vinogradarska kriza, propadanje jedrenjaštva i kriza ribarstva (Lajić, 1992). Za Istru se mogu navesti više-manje isti uzroci iseljavanja kao i za Dalmaciju. No kako su društveno-gospodarske prilike $u$ Istri bile ipak nešto povoljnije, ${ }^{4}$ to se odrazilo i na razmjerno manji obujam iseljavanja.

Prvi svjetski rat prekinuo je masovno iseljavanje u prekomorske zemlje. Nakon rata nastupile su prijelomne političko-teritorijalne promjene. Nastalo je više novih država, među kojima i Kraljevina SHS, u koju je ušla glavnina današnjeg teritorija Republike Hrvatske. No ostali su stari problemi (agrarna prenaseljenost, slaba industrijalizacija), a spori gospodarski rast nije nudio izlaz iz takva stanja. Razumije se da je zbog teških ekonomskih prilika postojao veliki iseljenički potencijal (Mirošević, 1988). No glavni kanali prekomorskog iseljavanja bili su sve uži. U strahu od novog vala južnoeuropske i istočnoeuropske imigracije SAD 1921. donosi krajnje restriktivne mjere u imigracijskoj politici (Zakon o kvotama), da bi nakon tri godine bio donesen još stroži zakon. Kvota je za svaku zemlju podrijetla smanjena na dva posto na temelju udjela pojedine etničke skupine u američkom stanovništvu 1890. (Nejašmić, 2005). ${ }^{5}$ Stoga iseljenički tokovi iz hrvatskih krajeva skreću prema Južnoj Americi, Kanadi i Australiji. No što zbog velike svjetske ekonomske krize, što zbog slabije razvijenosti i privlačnosti tih odredišta, iseljavanje nije imalo prijeratni intenzitet.

Koliki je broj prekomorskih iseljenika od početka stoljeća do Drugoga svjetskog rata? Na to je pitanje teško dati egzaktan odgovor. Kako je već istaknuto (v. Metodološke naznake), nedostaje pouzdanih podataka, a za neke krajeve i razdoblja uopće ih nema.

Prema podacima Zemaljskoga statističkog ureda u Zagrebu, od 1899. do 1913. iz Banske Hrvatske iselilo se 194.788 osoba; od tog broja $85,5 \%$ otišlo je u SAD (Lakatoš, 1914). ${ }^{6}$ Autorske procjene i izračuni za Bansku Hrvatsku kreću se od 244.000 iseljenika u razdoblju 1900. - 1913. (Lakatoš, 1914) do 300.000 za razdoblje koje završava Prvim svjetskim ratom (ali s otvorenim početkom razdoblja) (Lorković, 1939). ${ }^{7}$ Može se realnim prihvatiti broj od

4 Snažan razvoj triju gradova na njenim rubovima - Trsta, Rijeke i Pule - apsorbirao je dio viška agrarnog stanovništva (Šidak i dr., 1968).

5 Zakon donesen 1921. ograničio je broj doseljenika iz Kraljevine SHS na 6426, a prema kvoti iz 1924. na svega 671 osobu (Hranilović, 1987).

6 U taj su kontingent ubrojeni i iseljenici u europske zemlje; no oni su jako malobrojni, pa se navedeni podatak može smatrati brojem prekomorskih iseljenika.

7 Valja imati u vidu da je popis stanovništva 1900. ustanovio da 24.913 zavičajnika Banske Hrvatske živi u Americi (Statistički godišnjak, knj. I, 1913); za taj kontingent treba umanjiti najvišu procjenu. 
oko 260.000 iseljenika iz Banske Hrvatske u razdoblju 1900. - 1914. ${ }^{8}$

Za Dalmaciju i Istru nije bilo posebna statističkog praćenja iseljavanja i valja se osloniti na izračune i procjene relevantnih autora. Za Dalmaciju je M. Makale (1912) izračunao migracijski saldo za razdoblje 1890. - 1910; saldo je negativan i iznosi 58.158, što znači da se toliko više osoba iselilo nego doselilo, odnosno da je to najmanji mogući broj iseljenika. Naime taj bi broj valjalo uvećati za određeni kontingent koji se doselio u Dalmaciju. Ima li se u vidu da je iseljavanje bilo osobito snažno od 1910. do 1914., možemo procijeniti da se od 1900. do 1914. iz Dalmacije u prekomorske zemlje iselilo oko 75.000 osoba (11,5\% od ukupnog broja stanovnika pokrajine 1910.). Računa se da se do Prvoga svjetskog rata iz Istre (obuhvaća i kvarnerske otoke) iselilo oko 40.000 osoba (Lakatoš, 1914); možemo pretpostaviti da se veći dio iselio od 1900. do 1914., i to oko 25.000 osoba. Umanjimo li bruto iseljenički kontingent za 15 - 20\% povratnika, proistječe da se od 1900. do 1914. iz Hrvatske (današnji teritorijalni obuhvat) u prekomorske zemlje nepovratno iselilo oko 310.000 osoba, što je oko deset posto od prosječnog broja stanovnika. To znači da je u doba najjačeg vala prekomorskog iseljavanja kontingent iseljenih iz Hrvatske bio više-manje u okvirima europskog prosjeka. $^{9}$

Već je rečeno da je nakon Prvoga svjetskog rata znatno smanjeno iseljavanje iz Hrvatske u prekomorske zemlje. Od 1921. do 1929. iz Hrvatske, Slavonije i Dalmacije (odnosi se na tradicionalne pokrajine) u prekomorske se zemlje iselilo 78.399 osoba (Statistički godišnjak, 1929, 1932). Od 1930. do 1939. iz Banovine Hrvatske iselilo se oko 25.700 osoba, a glavnini je zavičaj bio u povijesnim pokrajinama Dalmaciji, Hrvatskoj i Slavoniji (Horvat, 1940). Proistječe da se od 1919. do 1939. iz Hrvatske (bez krajeva pod Italijom) iselilo oko 110.000 ljudi. ${ }^{10}$ Tom broju valja pribrojiti i iseljenike iz Istre; od 1918. do 1935. iz Istre, Trsta i Gorice iselilo se u prekomorske zemlje više od 25.000 Hrvata i Slovenaca (Radetić, 1944). S obzirom na udio istarskih Hrvata i Slovenaca u slavenskom korpusu navedenih regija može se pretpostaviti da je glavnina iseljenika bila iz Istre, otprilike 15.000. Proistječe da je u međuratnom razdoblju s teritorija današnje Hrvatske u prekomorske ze-

8 Dio županije Srijem nije izlučen premda nije u sastavu današnje Hrvatske; no može poslužiti (aproksimativno) kao nadomjestak za Međimurje i Baranju, koji su bili u sastavu Ugarske, a danas su dio Hrvatske.

9 Računa se da je od 1846. do 1924. iseljenički kontingent u prosjeku činio 12,3\% europskog stanovništva (Stalker, 2000).

10 Procjena je nešto veća od zbroja službenih podataka jer su se mnogi iselili, a da nisu nigdje registrirani (npr. pomorci koji su ostajali u lukama Novoga svijeta). 
mlje otišlo oko 125.000 osoba; računajući povratnu struju, u prekomorskoj je emigraciji izgubljeno oko 105.000 osoba.

Za cijelo razdoblje od 1900. do pred Drugi svjetski rat prekomorski iseljenički kontingent iznosi (neto) oko 415.000 osoba, ili oko 11,5\% prosječnog broja stanovnika, ili oko 10.000 osoba prosječno godišnje.

U vrijeme najvećeg vala prekomorskog iseljavanja europske zemlje nisu bile osobito privlačne stanovništvu Hrvatske. Od 1901. do 1910. iz Banske Hrvatske 18.144 osobe iselile su se u druge krajeve Austro-Ugarske, a u ostale europske zemlje 11.716 osoba, dakle ukupno 29.860 (Statistički godišnjak, 1913, 1917). Za Dalmaciju i Istru nema odgovarajućih podataka. Poslije Prvoga svjetskog rata iz hrvatskih krajeva odlazi »austrijsko« stanovništvo, odnosno šaroliki sastav iz više zemalja Monarhije (taj je kontingent $u$ analizi obuhvaćen u sklopu iseljavanja kao posljedice ratova). Što se tiče ekonomske emigracije, europska struja jača od 1923. do 1929., a od tada bitno slabi uslijed svjetske ekonomske krize, da bi ponovno ojačala nekoliko godine prije Drugoga svjetskog rata. Odlazi se na rad u Francusku i Belgiju, a pred rat u većem broju u Njemačku. S teritorija Banovine Hrvatske od 1927. do 1939. otišlo je u europske zemlje 46.686 osoba, a 1940. godine 7475 u Njemačku (Čizmić, 1976; Horvat, 1940). No ta je migracijska struja imala izrazito privremeno obilježje; povratna struja činila je i do $88 \%$ od broja otišlih u istom razdoblju (Čizmić, 1976). Na temelju parcijalnih podataka možemo procijeniti da se od 1900. do Drugoga svjetskog rata (bez iseljavanja vezanog uz Prvi svjetski rat) s današnjeg teritorija Hrvatske u europske zemlje nepovratno iselilo oko 25.000 osoba.

Poslije dvaju svjetskih ratova došlo je do krupnih političko-teritorijalnih promjena, a kao kolateralna pojava odvijala se i migracija stanovništva preko međunarodnih granica. Tako je tijekom rata, a posebice nakon raspada Austro-Ugarske, nastala snažna migracijska struja prema matičnim zemljama. Prethodno su desetljećima u hrvatske krajeve dolazili službenici, gospodarstvenici i stručnjaci iz drugih dijelova Monarhije: Austrije, Ugarske, Češke i drugih krajeva. U dijelove pod izravnom upravom Ugarske (Međimurje, Baranja) kolonizirani su seljaci. Taj se šaroliki kontingent velikim dijelom, zajedno sa svojim obiteljima, povukao u matične zemlje. O obujmu repatrijacije nema približnih podataka, no poznato je da je kod »političkih « migracija takva tipa obično riječ o velikom broju osoba. Procjenjujemo da je u toj ratnoj i neposredno poratnoj emigraciji sudjelovalo oko 160.000 osoba. ${ }^{11}$

11 Prema nekim indicijama može se pretpostaviti da se iselila trećina stanovnika čiji materinji jezik nije bio hrvatski ili srpski. Statistika pokazuje da je u Banskoj Hrvatskoj 1910., prema materinjem jeziku, popisan sljedeći broj stanovnika: češki 32.376, slovački 21.613, 
Drugi svjetski rat potaknuo je još veći val iseljavanja iz Hrvatske nego Prvi. Emigracijski kontingent činile se različite skupine: izbjeglice, osobe koje su ostale $\mathrm{u}$ inozemstvu kao ratni zarobljenici ili prisilni radnici, poražene vojne snage koje su se povukle s okupatorom, optanti, tj. stanovnici pripojenih krajeva koji su se opredijelili za iseljavanje u Italiju, iseljeni Nijemci, Česi, Mađari, Poljaci i pripadnici drugih nacionalnih skupina (repatrijacija) i prebjezi u prvim poratnim godinama. Prema relevantnim izvorima, od 1939. do 1948. emigriralo je iz Hrvatske (današnji teritorij bez pripojenih krajeva) 157.000 osoba (Žerjavić, 1989). No kako su godine 1939. i 1940. obuhvaćene u okviru međuratnog iseljavanja, taj broj valja umanjiti za nekoliko tisuća i zaokružiti na 152.000. Iz pripojenih krajeva (koji su prije Drugoga svjetskog rata bili pod Italijom) iselilo se do 15. ožujka 1948. oko 103.000 osoba (Žerjavić, 1989). ${ }^{12}$ Iz toga proistječe da ukupni »ratni« (četiri ratne godine s prvim poratnim godinama) iseljeni kontingent iznosi oko 255.000 osoba.

Nakon Drugoga svjetskog rata prihvaćen je Zakon o agrarnoj reformi i kolonizaciji (23. kolovoza 1945.), a organizirano seljenje trajalo je do 1948. (Maticka, 1990). U sklopu te »savezne kolonizacije« iz Hrvatske je u Vojvodinu naseljeno 9279 obitelji s 52.863 člana (Stipetić, 1954). S obzirom na to da je Republika Hrvatska danas neovisna država, poslijeratnu migraciju s bivšim jugoslavenskim republikama odlučili smo razmatrati u okviru vanjske migracije. Osim »kolonista « u toj su struji sudjelovali stručnjaci i drugi (osobnim izborom ili »dekretom«). Možemo procijeniti da se iz Hrvatske u druge republike, danas samostalne države, od 1945. do 1948. iselilo oko 85.000 osoba.

\section{Razdoblje 1948. - 1991.}

Iseljavanje iz Hrvatske od prvoga poslijeratnog popisa 1948. do popisa 1991. i raspada Jugoslavije obilježavaju tri glavne struje: a) iseljavanje u Italiju (optiranje) i drugo trajno iseljavanje (1948. - 1961.), b) iseljavanje nakon »otvaranja « granica (»odlazak na rad«) (1961. - 1991.) i c) iseljavanje u druge republike SFRJ (1948. - 1991.).

Pariški Ugovor o miru između Jugoslavije i Italije 1947. omogućio je optiranje za talijansko državljanstvo, a osim opcije moglo se iseliti i na temelju

mađarski 105.948 i njemački 134.078 (Popis žiteljstva od 31. XII. 1910., 1914). Veliki broj stanovnika čiji je materinji jezik bio talijanski ili neki od »austro-ugarskih« jezika živio je u Istri i Dalmaciji. Posebno je jaka repatrijacija bila iz Pule, koja je izgubila svoju osnovnu funkciju.

12 Žerjavić je bilanciranjem došao do 108.500 iseljenih osoba, ali taj broj valja korigirati za čisti demografski gubitak, tj. umanjeni natalitet. 
otpusta iz jugoslavenskog državljanstva za talijansko. ${ }^{13}$ Velike je razmjere poprimilo i ilegalno iseljavanje (prebjeg) jer mnogi stanovnici pripojenih krajeva nisu ispunjavali neke od glavnih uvjeta. ${ }^{14}$

Što legalno, a što ilegalno, iz Hrvatske se u Italiju do 1961. iselilo oko 200.000 osoba. ${ }^{15} \mathrm{~S}$ obzirom na to da je iz toga kontingenta 100.000 osoba obuhvaćeno u okviru iseljavanja povezanog s Drugim svjetskim ratom (i do popisa 1948.), ostaje ustvrditi kako se od 1948. do 1961. u Italiju iselilo oko 100.000 osoba. U tom se razdoblju (uglavnom do 1954.) odvijala i repatrijacija Mađara, Čeha i Slovaka (Rajaković, 1957). ${ }^{16}$ Za iseljavanje su upotrebljavane i druge pravne mogućnosti (npr. »spajanje obitelji«), a postupno se otvara i mogućnost odlaska na rad u inozemstvo. Možemo procijeniti da se na taj način od 1948. do 1961. iz Hrvatske iselilo oko 110.000 stanovnika.

Šezdesetih godina prošlog stoljeća dolazi do »otvaranja granica« i svojevrsnog obnavljanja ekonomske emigracije. Jugoslavija je bila jedina socijalistička zemlja koja je legalizirala odlazak, a čak ga je i poticala. Valja istaknuti da je tradicionalna prekomorska struja izgubila nekadašnju važnost, a glavnu ulogu preuzimaju zapadnoeuropska tržišta radne snage. Veliki broj odredišnih zemalja (»prijma radne snage«) jedno je od obilježja te etape vanjske migracije stanovništva Hrvatske (Nejašmić, 1995). Za analizu demografskih posljedica iseljavanja bitna je činjenica da se s vremenom "privremeni rad $\mathrm{u}$ inozemstvu « dobrim dijelom preobrazio $\mathrm{u}$ trajno iseljenje.

Nakon Drugoga svjetskog rata Hrvatska postaje dio nove države, a središte političke moći ponovno je izvan nje. To se nedvojbeno nepovoljno odražavalo na njezin društveno-gospodarski razvoj, a posljedično i na obujam iseljeničkog toka. Stoga kada govorimo o općim uzrocima iseljavanja, svakako su na prvome mjestu ekonomski čimbenici, no među »radnicima

13 Drugi sporazum o opcijama za talijansko državljanstvo bio je prihvaćen 1951. (Sl. list FNRJ, br. 1/1951. i 12/1951.). Treći sporazum potpisan je 1964. Konačno, mogućnost optiranja predviđa i Osimski sporazum iz 1975.

14 Zbog slabijeg udjela Talijana u ukupnom stanovništvu bilo je iz unutrašnjosti Istre više prebjega nego iz drugih pripojenih krajeva. Tako su se npr. iz općine Pazin (teritorijalni obuhvat iz osamdesetih godina) od 8440 iseljenih osoba od 1948. do 1969. ilegalno iselile 2292 osobe ili $27,2 \%$ (Nejašmić, 1980).

15 V. Holjevac (1967), inače dobar poznavatelj istarskih prilika prvih poratnih godina, navodi da je od 1945. do 1961. iz Istre otišlo 143.739 osoba. V. Zerjavić (1997) ustvrdio je da se iz Hrvatske iselilo 144.000 osoba (119.000 Talijana i 25.000 Hrvata). No u toj su struji sudjelovali i mnogi ilegalni migranti čiji je zavičaj bio izvan pripojenih krajeva. Značajni dio optanata, otpuštenih iz državljanstva i prebjega otišao je nakon kraćeg boravka u Italiji u prekomorske zemlje. Primjerice to su učinile dvije trećine iseljenih Hrvata iz općine Pazin (Nejašmić, 1980).

16 Nijemci su se uglavnom iselili potkraj rata i u analizi su obuhvaćeni u okviru »ratne« emigracije. 
migrantima « bio je nemali broj osoba koje su otišle zbog nezadovoljstva političkim prilikama u zemlji ili su bile izložene nekom obliku represije. Masovniji val »migracije radnika « počeo je 1968. Nepoljoprivredni gospodarski sektori nisu mogli apsorbirati svu radnu snagu koja je pridošla sa sela, pa je nezaposlenost sve više rasla. Osim toga petogodišnji plan razvoja zemlje (1966. - 1970.) predviđao je usporavanje stope zapošljavanja (WertheimerBaletić, 1969). Nedvojbeno bi dodatni porast nezaposlenosti izazvao ozbiljnu društvenu krizu. Stoga je spasonosni izlaz nađen $\mathrm{u}$ »otvaranju granica « i dopuštanju zapošljavanja stanovnika u inozemstvu. ${ }^{17}$ Masovnom odlasku pridonio je, posve razumljivo, i privlačni čimbenik - potražnja za svim profilima radnika, mogućnost višestruko veće zarade, povoljnije prilike za profesionalni rad u struci itd. (Županov, 1997). Tako je zapadnoeuropsko tržište privuklo ne samo deagrarizirano seljaštvo i nezaposlene nego i veliki broj zaposlenih osoba; takvih je među radnicima u tuđini 1971. bilo 47,4\%. »Obećana zemlja « postaje SR Njemačka, u kojoj je radilo 70,1\% od ukupnoga kontingenta »radnika migranata« iz Hrvatske 1971. (Nejašmić, 1995).

Već je rečeno da popisi stanovništva tek od 1971. obuhvaćaju "građane na radu u inozemstvu «, a od 1981. podrobnije i članove obitelji koji s njima borave. Popisi ionako nisu najbolji izvor za praćenje vanjske migracije; daju trenutačno stanje (»zamrznutu sliku«), i to svakih deset godina. Posebice su popisi nepouzdani u pogledu broja građana $u$ inozemstvu; računa se da je u prekomorskim zemljama obuhvaćen samo manji dio iseljenoga kontingenta. Ukupno se broj radnika u inozemstvu iz Hrvatske i članova njihovih obitelji kretao ovako: 1971. godine 254.856 (radnici 224.722, članovi obitelji 30.134), 1981. g. 210.330 (radnici 151.619, članovi obitelji 58.711) i 1991. g. 285.216 (radnici 175.338, članovi obitelji 109.878) (Nejašmić, 1995).

U početku se migracija radnika odvijala po modelu privremenih, cirkulirajućih radnika, tj. po modelu Gastarbeitera (»gostujućeg radnika«, pojam nastao u SR Njemačkoj). Računalo se da će u vrijeme konjunkture migranti osigurati potrebnu radnu snagu (a bez nekih važnijih društvenih i sindikalnih prava), a s nastupom krize vraćat će se kući. Širilo se mišljenje da taj model odgovara ne samo domaćinima već i samim migrantima te zemljama podrijetla (Bade, 1997). No s vremenom je ojačalo pretvaranje privremenih radnika migranata $u$ trajne migrante; radnik $u$ inozemstvu postaje iseljenik.

Možemo procijeniti da je od 1961. do 1991. na »rad u inozemstvo« iz Hrvatske otišlo oko 450.000 osoba (kumulativ). No već je 1981. bilo popi-

17 Hrvatska je u tome natprosječno sudjelovala. Tako je od ukupnog broja jugoslavenskih »radnika na privremenom radu u inozemstvu « 1971. godine $33,5 \%$ bilo iz Hrvatske, a udio stanovništva Hrvatske u ukupnom stanovništvu SFRJ iznosio je 21,6\%. 
sano 97.338 povratnika s »privremenog rada u inozemstvu«. Povratnički je kontingent posve sigurno bio veći; mnogi nisu obuhvaćeni popisom (kako je poznato, potpuni obuhvat populacije ionako nije moguć), dio povratnika umro je prije popisa, a nisu ni uvršteni povratnici koji su u inozemstvo otišli prije 1965. Po svemu sudeći, do 1991. kontingent povratnika (kumulativ) brojio je oko 150.000 osoba. Proistječe da broj trajnih vanjskih migranata, tj. iseljenički kontingent, za razdoblje 1961. - 1991. iznosi oko 300.000 osoba, ili prosječno 10.000 godišnje. Procjenjujemo da se od toga kontingenta na prekomorsku struju odnosi oko 40.000 (od toga su mnogi reemigrirali iz europskih zemalja), a na europsku 260.000 osoba.

Već je istaknuto da poslijeratnu migraciju s bivšim jugoslavenskim republikama razmatramo u okviru vanjske migracije. To je učinjeno i za razdoblje 1948. - 1991. Prema relevantnim izvorima može se ustvrditi da se $\mathrm{u}$ tome razdoblju iz Hrvatske $\mathrm{u}$ druge republike SFRJ (danas samostalne države) iselilo oko 350.000 osoba (Breznik, 1975; Stevanović i Breznik, 1986; Žuljić, 1989). ${ }^{18}$

\section{Razdoblje 1991. - 2001.}

Početkom devedesetih Hrvatska ulazi u jednu od posebnijih etapa svoga društveno-političkog i demografskog razvoja. Agresija i rat na njezinu teritoriju te poratne i tranzicijske teškoće, uz neizbježan utjecaj na društvena zbivanja i procese, posebice su uzdrmali demografska kretanja. Ratna agresija na Hrvatsku početkom devedesetih izazvala je vrlo jako iseljavanje. Migracijski gubici kao posljedica rata iznose 418.507 osoba, ili 93\% ukupnih demografskih gubitaka u Domovinskom ratu (Živić i Pokos, 2004). Na temelju podataka o broju doseljenih osoba u međupopisnome razdoblju 1991. - 2001., podataka vitalne statistike te primjene vitalnostatističke metode za utvrđivanje migracije, možemo procijeniti da se od 1991. do 2001. iselilo oko 500.000 osoba, što je 11,5\% prosječnog broja stanovnika. ${ }^{19} \mathrm{Tu}$ je emigracijsku struju uglavnom izravno uzrokovao rat (izbjeglice), ali i gospodar-

18 S obzirom na to da je Hrvatska bila razmjerno razvijena republika, privlačila je stanovništvo iz drugih krajeva Jugoslavije. Prema istim izvorima, doseljavanje je bilo znatno jače od iseljavanja. Od 1948. do 1991. doselilo se 531.800 osoba (75\% iz BiH); dakle bilanca je pozitivna i iznosi 181.800 osoba.

19 Prema službenoj statistici (Migracija stanovništva Republike Hrvatske u 2002.), saldo vanjske migracije za razdoblje 1993. - 2001. pozitivan je i iznosi 269.966 osoba. Da je riječ o potpuno nepouzdanoj evidenciji, pokazuje podatak o saldu dobivenom vitalnostatističkom metodom, koji za razdoblje 1991. - 2001. iznosi -299.000 (više o tome u poglavlju o bilanci vanjske migracije), ili -247.300 ako se računa na temelju rezidencijalnog stanovništva 1991. (prema Gelo, Akrap i Čipin, 2005). To je, zapravo, razlika između doseljenih i iseljenih, odnosno najmanji mogući broj iseljenika. 
ske i društvene teškoće inducirane ratom (Lajić, 1995; Pokos, 1999). Većinu iseljenoga kontingenta činili su izbjegli pripadnici srpske manjine; prema kumulativnim podacima, 2001. bilo ih je oko 270.000 (Živić i Pokos, 2004). Iz toga proizlazi da se u ostalim iseljeničkim strujama iz Hrvatske iselilo oko 230.000 osoba. Iseljavalo se u zapadnoeuropske i prekomorske zemlje, ali i u zemlje republike bivše SFRJ.

\section{Pregled emigracijskih tokova 1900. - 2001.}

Proistječe da je tijekom 20. stoljeća s teritorija današnje Republike Hrvatske neprekidno tekla široka rijeka iseljenika; iselilo se 2,3 milijuna ljudi. Intenzitet iseljavanja iz Hrvatske po glavnim etapama, odnosno podrazdobljima, tekao je ovako: od početka 20. stoljeća do nekoliko godina poslije Drugoga svjetskog rata (1900. - 1948.) iselilo se $26,7 \%$ prosječnog broja stanovnika ili oko 19.600 prosječno godišnje, od Drugoga svjetskoga rata do raspada druge Jugoslavije (1948. - 1991.) otišlo je 20,1\% prosječnog broja stanovnika ili oko 20.000 godišnje, a u desetljeću samostalne Hrvatske (1991. - 2001.) iselilo se $11,5 \%$ prosječnog broja stanovnika ili oko 50.000 prosječno godišnje.

Činjenica da iseljavanje s vremenom nije jenjavalo ima s gledišta utjecaja iseljavanja na demografske promjene jednaku važnost kao i obujam izlaznog toka. Nema dvojbe da je snažno iseljavanje vrlo nepovoljno utjecalo na razvoj stanovništva Hrvatske (podrobnije o tome u sljedećem poglavlju). Populacija koja je već 1948. bila na pragu demografskog starenja (indeks starosti 25,2 ) ne bi mogla bez težih posljedica izdržati ni puno slabiju emigraciju od predočene. No da je izostao, ili barem oslabio, snažni odljev »ljudskoga kapitala« od šezdesetih godina 20. stoljeća naovamo, a s obzirom na to da je Hrvatska imala pozitivnu međurepubličku migracijsku bilancu (vidi bilješku 18), možemo ustvrditi da bi današnje demografske prilike bile znatno povoljnije.

Ustvrdili smo da je u emigracijskoj struji sudjelovao šaroliki etnički sastav, ali je posve jasno da se najveći dio odnosi na Hrvate. Među iseljenicima je bilo oko 380.000 »stranaca « (»austro-ugarsko« stanovništvo nakon Prvoga svjetskog rata, Talijani i Nijemci povezano s Drugim svjetskim ratom itd.). Kada se od 2,3 milijuna iseljenih osoba odbije spomenuti kontingent »stranaca «, proistječe da se iz Hrvatske iselilo oko 1,92 milijuna domaćeg stanovništva. Uvažavajući etnički sastav te imajući u vidu razmatrana osnovna obilježja emigracije iz Hrvatske, možemo procijeniti da je u iselje- 
nom kontingentu bilo oko 1,52 milijuna Hrvata. ${ }^{20}$ Dakle riječ je o populacijskom i etničkom gubitku hemoragijskih dimenzija.

Tablica 1. Pregled glavnih tokova i intenziteta iseljavanja iz Hrvatske 1900. - 2001. (procjena)

Table 1. Overview of the main flows and intensity of emigration from Croatia, 1900-2001 (estimate)

Broj osoba

\begin{tabular}{|c|c|}
\hline $\begin{array}{l}\text { Prekomorsko iseljavanje od 1900. do Drugoga svjetskog } \\
\text { rata }\end{array}$ & 415.000 \\
\hline $\begin{array}{l}\text { Iseljavanje u europske zemlje od 1900. do Drugoga } \\
\text { svjetskog rata }\end{array}$ & 25.000 \\
\hline $\begin{array}{l}\text { Iseljavanje »austrougarskog « stanovništva povezano s } \\
\text { Prvim svjetskim ratom }\end{array}$ & 160.000 \\
\hline $\begin{array}{l}\text { Iseljavanje povezano s Drugim svjetskim ratom (do } \\
\text { 1948.) }\end{array}$ & 255.000 \\
\hline $\begin{array}{l}\text { Iseljavanje u sklopu tzv. savezne kolonizacije (1945. - } \\
\text { 1948.) i ostalo }\end{array}$ & 85.000 \\
\hline Svega 1900. - 1948. & 940.000 \\
\hline Iseljavanje u Italiju (1948. - 1961.) & 100.000 \\
\hline Repatrijacija i drugi oblici iseljavanja (1948. - 1961.) & 110.000 \\
\hline Iseljavanje nakon »otvaranja« granica (1961. - 1991.) & 300.000 \\
\hline Iseljavanje u druge republike bivše države (1948. - 1991.) & 350.000 \\
\hline $\begin{array}{l}\text { Svega 1948. - } 1991 . \\
\end{array}$ & 860.000 \\
\hline $\begin{array}{l}\text { Iseljavanje uglavnom povezano s Domovinskim ratom } \\
(1991 . \text { - 2001.) }\end{array}$ & 500.000 \\
\hline Svega 1991. - 2001. & 500.000 \\
\hline Ukupno 1900. - 2001. & 2.300 .000 \\
\hline
\end{tabular}

20 Klasično prekomorsko iseljavanje bilo je najjače iz krajeva u kojima su Hrvati činili veliku većinu stanovništva. U novijoj vanjskoj migraciji Srbi su sudjelovali osjetno ispod svoga udjela u populaciji Republike Hrvatske. Prema podacima popisa stanovništva 1981., činili su 11,5\% ukupne populacije, dok ih je među "radnicima u inozemstvu « bilo 7,5\% (Popis stanovništva, domaćinstava i stanova 1981., Dokumentacija 501). Jače iseljavanje Srba (izbjeglištvo) zabilježeno je tijekom Drugoga svjetskog rata, a posebice za vrijeme Domovinskog rata. 


\section{Bilanca vanjske migracije 1900. - 2001.}

Iseljavanje nije uputno razmatrati bez spoznaje o doseljavanju (»kontratoku«). Valja istaknuti da je kroz cijelu svoju povijest prostor Hrvatske privlačio doseljeničke struje, koje su utjecale, između ostaloga, na oblikovanje hrvatskoga kulturnog identiteta i demografskih značajki stanovništva. Tijekom 19. stoljeća doseljavali su se Česi, Mađari, Slovaci, Nijemci i Talijani, a u 20. stoljeću pretežito pripadnici naroda iz zajedničkih država (ZlatkovićWinter, 1993; Heršak, 1993). Tako se primjerice u vrijeme najjačeg iseljavanja u prekomorske zemlje (1900. - 1910.) u kraljevine Hrvatsku i Slavoniju doselilo 43.000 stranaca (Gelo, 1987). V. Horvat (1942: 62) navodi da se od 1918. do 1938. u Istočnu Hrvatsku naselilo iz "Češke i Slovačke i drugih država 6400 seljačkih obitelji«. Iz drugih republika bivše državne zajednice od 1948. do 1991. doselilo se 531.800 osoba (vidi bilješku 18) itd.

Migracijski saldo za razdoblje 1900. - 2001. izračunan vitalnostatističkom metodom iznosi -1.200.000 osoba. ${ }^{21}$ Budući da se iselilo 2.300 .000 osoba, proistječe da se $\mathrm{u}$ istom razdoblju na teritorij današnje Hrvatske doselilo oko 1.100 .000 osoba (tablica 2). ${ }^{22}$ Od tog se kontingenta $34,7 \%$ osoba doselilo u prvoj polovini 20. stoljeća (točnije, do 1953.). Doseljenički je tok $\mathrm{s}$ vremenom jačao, s naglaskom prema novijem razdoblju. Znakovito je da se najveći intenzitet doseljavanja (kao i iseljavanja) odvijao u desetljećima obilježenima ratom na tlu Hrvatske i poratnim događajima (1940. - 1948. i 1991. - 2001.).

Doseljavanje je blagotvorno djelovalo na ublažavanje negativnih posljedica dugotrajnog i snažnog iseljavanja. Da nije bilo »ulaznog toka vanjske migracije«, danas bi Hrvatska imala ne samo znatno manje stanovnika (manje i za doseljenički prinos prirodnom prirastu) već i još stariju populaciju, »S manjim udjelom radnosposobnoga stanovništva (u dobi 15 do 65 godina), s manjim udjelom djece i bili bismo u još nepovoljnijoj demografskoj

${ }^{21}$ Za način izračunavanja migracijskog salda vitalnostatističkom metodom vidi Metodološke naznake. Za pojedine popisne godine izvor su podataka službeni popisni podaci (Državni zavod za statistiku). Prirodna promjena za razdoblje 1900. - 1948. izračunana je temeljem godišnjih stopa prirodne promjene preuzetih iz: J. Gelo (1987); za ostala razdoblja upotrijebljena je vitalnostatistička dokumentacija DZS-a.

22 Razmatrajući razdoblje 1901. - 2000., J. Gelo (Gelo, Akrap i Čipin, 2005) došao je do nešto većih bilančnih »stavki«. Doseljenih je 1.385.700, iseljenih 2.655.500, a bilanca vanjske migracije iznosi - 1.269.800. Valja istaknuti da je autor rabio nešto drukčije parametre izračuna, iz čega i proistječu spomenute razlike. Naime razmatra rezidencijalno stanovništvo (»stvarno boraveće«), što znači da od 1971. do 1991. vanjske migrante na »privremenom radu « tretira kao iseljenike i ne obuhvaća ih u ukupno stanovništvo, iako se samo dio toga kontingenta transponirao u stalno iseljeništvo. Nadalje, čini se precijenjenim i broj doseljenika od 1911. do 1920. (194.000 osoba), što pak u bilanciranju povećava i iseljenički tok. 
situaciji« (Gelo, Akrap i Čipin, 2005: 75). Zapravo je doseljavanje odgodilo hrvatski »demografski slom«, pomaknulo ga s polovine 20. stoljeća na njegov kraj.

Tablica 2. Bilanca vanjske migracije stanovništva Hrvatske (današnji teritorijalni obuhvat) od 1900. do 2001. (procjena)*

Table 2. Emigration balance of the Croatian population (today's territorial coverage), 1900-2001 (estimate)

\begin{tabular}{|c|c|c|c|c|}
\hline \multirow[b]{2}{*}{ Razdoblje } & \multirow[b]{2}{*}{ Doseljeni } & \multirow[b]{2}{*}{ Iseljeni } & \multicolumn{2}{|c|}{ Migracijska bilanca } \\
\hline & & & ukupno & $\begin{array}{r}\text { prosječno } \\
\text { godišnje }\end{array}$ \\
\hline 1900. - 1910. & 100.000 & 235.000 & -135.000 & -13.500 \\
\hline 1910. - 1914. & 40.000 & 95.000 & -55.000 & -13.750 \\
\hline 1914. - 1921. & 4000 & 162.000 & -158.000 & -22.571 \\
\hline 1921. - 1931. & 15.000 & 73.000 & -58.000 & -5800 \\
\hline 1931. - 1940. & 10.000 & 55.000 & -45.000 & -5000 \\
\hline 1940. - 1948. & 168.000 & 320.000 & -152.000 & -19.000 \\
\hline 1948. - 1953. & 45.000 & 110.000 & -65.000 & -13.000 \\
\hline 1953. - 1961. & 110.000 & 220.000 & -110.000 & -13.750 \\
\hline 1961. - 1971. & 147.000 & 146.000 & 1000 & 100 \\
\hline 1971. - 1981. & 150.000 & 181.000 & -31.000 & -3100 \\
\hline 1981. - 1991. & 110.000 & 203.000 & -93.000 & -9300 \\
\hline 1991. - 2001. & 201.000 & 500.000 & -299.000 & -29.900 \\
\hline 1900. - 2001. & 1.100 .000 & 2.300 .000 & -1.200 .000 & -11.881 \\
\hline
\end{tabular}

* Sve računske stavke zaokružene su na 1000, osim prosječne godišnje bilance. Procjena uključuje i migraciju s republikama bivše države. Od 1961. do 2001. dio iseljenoga kontingenta koji se odnosi na iseljavanje u inozemstvo (izvan granica bivše SFRJ) zapravo predstavlja »transponirani« kontingent privremene u trajnu emigraciju.

Izvor: Procjena je temeljena na vitalnostatističkoj metodi izračunavanja migracijskog salda upotrebom podataka službene statistike (broj stanovnika za 1914. prema J. Gelo, 1987; za 1940. procijenio autor ekstrapolacijom trenda) te sekundarnih izvora u analitičkom dijelu rada.

Predočene bilančne stavke pokazuju da se u razmatranom stoljeću odvijala snažna vanjska migracija stanovništva Hrvatske. Zbroje li se iseljeni i useljeni kontingent (bruto migracija), proistječe da je u migraciji preko da- 
našnje međunarodne granice sudjelovalo oko 3,4 milijuna ljudi. O kolikom je razmjeru tog fenomena riječ, pokazuje podatak da je toliko iznosio broj stanovnika Hrvatske 1921. (3,45 milijuna). Omjer »ulazne« i »izlazne« struje jest 1 : 2,1. Migracijski gubitak od 1,2 milijuna ljudi iznosi 33,4\% prosječnog broja stanovnika (u smislu aritmetičke sredine) ili 52\% kumulativne prirodne promjene (prirasta). Hrvatska je dakle u dugom razdoblju vanjskom migracijom prosječno godišnje gubila 11.881 stanovnika, ili svakodnevno 32,5 stanovnika.

\section{DEMOGRAFSKE POSLJEDICE ISELJAVANJA}

Rezultati analize potvrđuju navod iz uvoda kako je malo zemalja koje su imale tako značajan gubitak stanovništva u migracijskim tokovima kao Hrvatska. ${ }^{23}$ Posebice zabrinjava iseljavanje (migracijski gubitak) posljednjih desetljeća jer se odvija u okolnostima smanjene rodnosti, negativne prirodne promjene, depopulacije i starenja stanovništva.

\section{Promjene broja stanovnika i prostorni razmještaj}

Budući da iseljavanje uz ostale nepromijenjene uvjete smanjuje broj stanovnika, nameću se pitanja: koliko je iseljavanje utjecalo na gubitak stanovništva? Koliko bi Hrvatska imala stanovnika da nije bilo iseljavanja?

Osim iseljavanjem Hrvatska je gubila stanovništvo i zbog ratova i bolesti. Dva svjetska rata i Domovinski rat ostavili su teške posljedice. S obzirom na to da je migracija povezana s ratovima posebno obrađena, a to ćemo učiniti i s epidemijama, ostaje utvrditi koliki su bili čisti demografski gubici (smanjeni natalitet) i ratni gubici (izravno ili posredno vezano uz ratna stradanja). Procijenjeni gubici u ratovima: a) čisti demografski gubici (smanjeni natalitet): Prvi svjetski rat 113.000, Drugi svjetski rat 70.000, Domovinski rat 9600, ukupno (zaokruženo) 193.000, b) ratni mortalitet: Prvi svjetski rat 95.000, Drugi svjetski rat 310.000, Domovinski rat 22.192, ukupno (zaokruženo) 427.000 (Nejašmić, 2008). Rezultat zbrajanja obiju kategorija daje gubitak od 620.000 stanovnika.

Prvi svjetski rat razbuktao je i epidemije zaraznih bolesti. Javljaju se epidemije kolere i dizenterije. No najpogubnija je bila epidemija gripe 1918 . - 1919., koja je imala pandemijska obilježja (»španjolska gripa«). U kralje-

23 Često se Hrvatsku nekritički uspoređuje s Irskom. Ta je zemlja pravi »emigracijski fenomen«. Samo između 1820. i 1860. u SAD se uselilo gotovo dva milijuna Iraca, a kako se iseljavanje nastavilo, to je dovelo do toga da je Irska jedina europska zemlja koja je $\mathrm{u}$ prvoj polovini 19. stoljeća imala više stanovnika nego danas, i to dvostruko više (Salins, 1997). 
vinama Hrvatskoj i Slavoniji od 1. siječnja 1918. do 30. lipnja 1919. (podaci nisu potpuni) gripa je odnijela 33.831 život (Bogić, 1922). Uzmemo li u obzir cijeli današnji teritorij Hrvatske, odnosno odgovarajuću populaciju, broj žrtava gripe možemo procijeniti na oko 45.000. U međuratnome razdoblju oslabjeli su epidemijski valovi, a zahvaćali su uglavnom manja područja (Pirc, 1929). Prema dostupnim parcijalnim podacima, ukupni epidemijski pomor u Hrvatskoj u međuratnom razdoblju možemo procijeniti na oko 15.000 umrlih. Drugi svjetski rat potaknuo je i širenje zaraznih bolesti, a glavni epidemiološki problem bio je tifus (pjegavac). U Lici, Banovini i Kordunu tijekom rata od tifusa je umrlo 13.109 osoba, od čega se gotovo polovina odnosi na Kordun (47\%) (Žerjavić, 1989). S obzirom na iznimno teške opće, a posebice zdravstvene prilike možemo računati da je tijekom rata od epidemija umrlo oko 15.000 stanovnika Hrvatske (odnosi se na populaciju u okviru današnjega državnog teritorija). Zbrajanjem predočenih (procijenjenih) podataka proistječe da su epidemije na tlu Hrvatske od 1900. do kraja Drugoga svjetskog rata odnijele oko 75.000 života.

Ukupni procijenjeni populacijski gubitak u 20. stoljeću iznosi 1.895 .000 osoba, a pojedine kategorije imaju sljedeći udio: negativna bilanca vanjske migracije (1.200.000) 63,3\%, ratni gubici (620.000) 32,7\% i epidemije (75.000) $4,0 \%$. Dobili smo odgovor na prvo pitanje: iseljavanje, koje je bilo dvostruko veće od doseljavanja, najveći je krivac za gubitak stanovništva Hrvatske od 1900. do 2001. Valja istaknuti da u iseljavanje nije uračunat gubitak uslijed odnesenog vitalnog potencijala, točnije rečeno izgubljenoga prirodnog prirasta. To će biti učinjeno u traženju odgovora na drugo pitanje.

U 18. stoljeću broj stanovnika na teritoriju današnje Hrvatske povećao se 2,5 puta (godine 1800. bilo je 1.595 .143 stanovnika), a u 19. stoljeću udvostručio (indeks 198,2) (Gelo, 1987). Između 1900. i 2001. povećanje broja stanovnika iznosi 40,4\%; u drugoj polovini tog razdoblja (1953. - 2001.) iznosi svega $12,7 \%$. Popis 2001. zabilježio je 4.437 .460 stanovnika (tablica 3). Praktično nijedna europska zemlja, s izuzetkom Irske, nije imala tako slab porast stanovništva tijekom 20. stoljeća (Gelo, 2004). ${ }^{24}$ Prosječni godišnji porast bio je 12.634 osobe, a prosječna godišnja stopa promjene 3,51\%o. Na spori rast stanovništva Hrvatske utjecalo je mnoštvo čimbenika (društveni, politički, vojni i gospodarski), i to prije svega djelujući na iseljavanje najproduktivnijih i najvitalnijih naraštaja.

Izračun za hipotetičnu »zatvorenu populaciju « (dakle bez vanjske migracije) kumuliranjem međupopisne prirodne promjene (prirast je iznosio

${ }^{24}$ Nisu uračunate državice kao Vatikan, San Marino, Andora i Monako. 
2.283.500) pruža djelomičan odgovor na drugo pitanje. Možemo ustvrditi: da nije bilo iseljavanja ni doseljavanja, Hrvatska bi 2001. imala 5.444.956 stanovnika, ili $22,7 \%$ više od popisanoga (tablica 3 ).

Tablica 3: Kretanje ukupnoga broja stanovnika Hrvatske 1900. - 2001., prema popisima i u hipotetičnoj »zatvorenoj populaciji«

Table 3. Total population trends in Croatia from 1900 to 2001, according to censuses and in a hypothetical "closed population"

\begin{tabular}{cccc}
\hline $\begin{array}{c}\text { Godina } \\
\text { popisa }\end{array}$ & $\begin{array}{c}\text { Broj stanovnika } \\
\text { prema popisima }\end{array}$ & $\begin{array}{c}\text { Prirodna promjena } \\
\text { (prirast) između } \\
\text { dvaju popisa }\end{array}$ & $\begin{array}{c}\text { "Zatvorena } \\
\text { populacija « }\end{array}$ \\
\hline 1900. & 3.161 .456 & - & 3.161 .456 \\
\hline 1910. & 3.460 .584 & 433.900 & 3.595 .356 \\
\hline 1921. & 3.443 .375 & 193.350 & 3.788 .706 \\
\hline 1931. & 3.785 .455 & 400.800 & 4.189 .506 \\
\hline 1948. & 3.779 .858 & 190.350 & 4.379 .856 \\
\hline 1953. & 3.936 .022 & 221.400 & 4.601 .256 \\
\hline 1961. & 4.159 .696 & 331.100 & 4.932 .356 \\
\hline 1971. & 4.426 .221 & 265.500 & 5.197 .856 \\
\hline 1981. & 4.601 .469 & 206.000 & 5.403 .856 \\
\hline 1991. & 4.784 .265 & 89.500 & 5.493 .356 \\
\hline 2001. & 4.437 .460 & -48.400 & 5.444 .956 \\
\hline
\end{tabular}

* Broj stanovnika na temelju prirodne promjene (prirasta), bez »bilančnih stavki« vanjske migracije.

Izvor: Statistički ljetopis Hrvatske 2002., DZS, Zagreb; za prirodnu promjenu vidi bilješku 21.

Broj od 5,44 milijuna predstavlja donju razinu hipotetične »zatvorene populacije«, tj. najmanji mogući broj stanovnika. Naime u izračunu koji se temelji na ostvarenome prirodnom prirastu nedostaje dio prirasta koji bi bio ostvaren da nije bilo populacijskoga gubitka u vanjskoj migraciji. Primjenom ostvarenih prosječnih stopa prirodnog prirasta (kretale su se od 13,5\%o u razdoblju 1900. - 1910. do $-0,5 \%$ o u posljednjemu međupopisnom razdoblju) na »zatvorenu populaciju « prirodna promjena postaje veća za 570.000 osoba od ostvarene (ili $25 \%$ ). Taj ćemo broj dodatno korigirati uvažavajući činjenicu da bi se bez utjecaja vanjske migracije proces demografske tranzicije odvijao sporije, odnosno stope prirodne promjene stanovništva Hrvat- 
ske poslije Drugoga svjetskog rata, iako u silaznom trendu, bile bi osjetno više od ostvarenih. ${ }^{25} \mathrm{Na}$ tu stavku odnosi se oko 200.000 osoba. Dakle da nije bilo vanjske migracije (ni iseljavanja ni useljavanja), prirodna promjena (prirast) bila bi veća za 770.000 osoba ili za 33,7\% u odnosu na ostvarenu. Za toliko valja povećati i ukupni broj stanovnika hipotetične "zatvorene populacije«. Možemo ustvrditi: da nije bilo vanjske migracije u razdoblju 1900. - 2001. (u kojem se, kako znamo, dogodio veliki »bilančni manjak«, tj. dvostruko jače iseljavanje nego doseljavanje), Hrvatska bi 2001. imala najmanje 6.215.000 stanovnika, što znači 1.777.540, ili 40,1\% više od popisanog broja. ${ }^{26}$ Znači, unatoč gubicima u ratovima i epidemijama stanovništvo Hrvatske u odnosu na početak 20. stoljeća gotovo bi se udvostručilo (indeks 2001./1900. iznosio bi 196,6).

Predočeni nalazi jasno upućuju na glavni uzročnik depopulacije Hrvatske. Popis 2011. zabilježio je 500.000, ili 10,5\% osoba manje nego 1991.; u posljednjemu međupopisnom razdoblju (2001. - 2011.) smanjenje iznosi 3,5\%. Unatoč različitim metodološkim pristupima u utvrđivanju ukupnog broja stanovnika u uspoređivanim popisima, nema sumnje da je na djelu ukupna depopulacija; pitanje je samo kolikog intenziteta. Tome svjedoči i prirodna depopulacija (negativna prirodna promjena), koja za razdoblje 1991. - 2001. iznosi 48.400 osoba. Očigledno je depopulacija Hrvatske ušla u posljednju razvojnu fazu tog procesa - fazu izumiranja stanovništva (Wertheimer-Baletić, 1999). Da je tome tako, pokazuju i relevantne projekcije prema kojima će se broj stanovnika Hrvatske do 2031. smanjiti (polazeći od stanja 2001., po varijanti srednjeg fertiliteta i bez vanjske migracije) za 17,1\% (Nejašmić i Mišetić, 2004), odnosno za 25,5\% do 2050. (Gelo, Akrap i Čipin, 2005). Nakon 19. stoljeća, u kojem je populacija Hrvatske udvostručena, i 20. stoljeća, u kojem je zabilježen slabi rast, 21. stoljeće obilježit će depopulacija. U kolopletu čimbenika koji utječu na takvu demografsku perspektivu svakako važnu ulogu ima izrazito negativna bilanca vanjske migracije iz analiziranog razdoblja.

Vanjska migracija imala je značajnu ulogu i u (pre)razmještaju stanovništva Hrvatske. Najkraće rečeno, iseljenički i useljenički tokovi prostorno

${ }^{25}$ Nije moguće ni približno točno odrediti kolike bi bile stope prirodne promjene da je izostao utjecaj negativnoga migracijskog salda u tako dugom razdoblju. S obzirom na obujam iseljavanja možemo tek pretpostaviti da bi za međupopisna razdoblja poslije Drugoga svjetskog rata prosječne stope prirodne promjene bile veće od ostvarenih za $10-20 \%$.

26 Valja istaknuti da to nije broj stanovnika koji bi imala Hrvatska 2001. da nije bilo stoljetnog iseljavanja. To je rezultat bez vanjske migracije, dakle pokazuje koliko bi iznosio ukupni broj stanovnika bez izlaznog i ulaznog toka vanjske migracije. Da nije bilo iseljavanja, a uz ostvareno doseljavanje (1.100.000), Hrvatska bi 2001. imala oko 7.315 .000 stanovnika, ili $65 \%$ više od popisanog broja. 
su selektivni. Tako su glavninu prekomorskih iseljenika davala siromašna ruralna područja (mahom krška): Gorski kotar, Lika, Žumberak, otoci i dijelovi priobalja (Nejašmić, 1991). U kasnije migracijske tokove uključila su se i druga područja: Dalmatinska zagora, Kordun i Banovina. Iseljavanje je bilo inicijalni čimbenik populacijskog pražnjenja tih krajeva; poslije su do punog izražaja došli i drugi čimbenici. Čak je i povratnička iseljenička struja dijelom pridonijela pražnjenju emigracijskih krajeva, i to zato što su mnogi povratnici stečenim kapitalom kupili imanja ili započeli neku poduzetničku aktivnost u razvijenijim krajevima (plodnijima, prometno dostupnijima). $S$ druge strane, doseljenike su u pravilu privlačili bogatiji ravničarski krajevi i gradovi. ${ }^{27}$ Time je vanjska migracija obujmom i prostornom selektivnošću svojih ulaznih i izlaznih tokova značajno utjecala na diferencirani regionalni demografski razvoj Hrvatske i na značajke naseljenosti. ${ }^{28}$

\section{Prirodno kretanje}

U prethodnom smo odjeljku ustvrdili da je migracijski gubitak uzrokovao smanjenje mase prirodne promjene (prirasta) i da manjak iznosi 770.000 osoba. Iseljavanje je kroz sužavanje fertilnih kohorti dovelo do smanjenja rađanja, ali i do povećanja stope smrtnosti. Naime iseljava se uglavnom mlađe stanovništvo, koje je ujedno manje podložno mortalitetu. Iseljavanje u pravilu najjače zahvaća kontingent stanovništva u dobi od 20 do 45 godina (Rogers, 1984). Tako je bilo i u slučaju Hrvatske. U vrijeme najjačega prekomorskog iseljavanja, 1901. - 1912., 58\% iseljenika iz Banske Hrvatske bilo je u dobi od 20 do 39 godina (Lakatoš, 1914). Slično je bilo i u Dalmaciji; u prvom desetljeću nakon Prvoga svjetskog rata najviše iseljenika bilo je u dobi između 18 i 30 godina, i to 49,3\%, te mlađih od 18 godina, 17,8\% (djeca koja su se iselila s roditeljima); starijih od 50 godina bilo je samo 2,9\% (Mirošević, 1988). Znakovit je podatak na razini cijele Hrvatske: kohorta muškog stanovništva u dobi od 20 do 39 godina brojila je 1900. godine 418.431 osobu, a popis 1910. zabilježio je $\mathrm{u}$ toj kohorti (starijoj za deset godina, dakle $\mathrm{u}$ dobi od 30 do 49 godina) 54.000 ili 13\% osoba manje (prema Gelo, Akrap i

27 Za ilustraciju navedenoga može poslužiti doseljavanje u Gradsku zajednicu općina Zagreb (dakle šire gradsko područje). Od 1976. do 1981. Zagreb je primio 30\% ukupnog broja doseljenika iz Bosne i Hercegovine (iz koje je i inače najveći broj doseljenika), svakog trećeg doseljenika s Kosova, svakog četvrtog iz Makedonije itd. (Popis stanovništva, domaćinstava $i$ stanova 1981., Dokumentacija 553). Sudeći prema zagrebačkome primjeru, možemo reći da su i ostala velika urbana središta privukla glavninu tih doseljenika.

28 Tome svjedoči i primjer hrvatskog otočja, čije se stanovništvo rano uključilo u emigracijske tokove. Zbog toga (ali i drugih čimbenika) danas otočje uvelike obilježavaju depopulacija, visoki stupanj ostarjelosti stanovništva i demografsko izumiranje (Lajić i Mišetić, 2006; Nejašmić, 2013). 
Čipin, 2005). Razumije se, manji je broj umro, ali je na tako značajno smanjenje kontingenta najvitalnijega (muškog) stanovništva nedvojbeno utjecalo iseljavanje. $\mathrm{U}$ iseljavanju iz Istre $\mathrm{u}$ Italiju nakon Drugoga svjetskog rata sudjelovale su cijele obitelji (optiranje), ali su ipak značajni dio činile mlađe osobe. Primjer Pazinštine pokazuje da je gotovo polovina iseljenika $(47,4 \%)$ bila u dobi od 19 do 29 godina (Nejašmić, 1980). Imajući u vidu prostornu selektivnost tog procesa, možemo reći da je u izrazito emigracijskim krajevima fertilni kontingent (muškoga) stanovništva nerijetko bio gotovo prepolovljen.

Takvo smanjivanje najvitalnijega kontingenta stanovništva rezultiralo je padom broja rođenih. Od 1910. do 1940. broj rođenih smanjivao se prosječno 1\% godišnje (Gelo, 1987). No na takvu dinamiku smanjenja rodnosti osim iseljavanja utjecali su i rat te sekularno (tranzicijsko) smanjenje nataliteta. Odgođeni (dugoročni) učinak iseljavanja osjećao se i nakon isteka jednoga ili više desetljeća jer su brojčano »okljaštreni« naraštaji imali osjetno manji reproduktivni učinak. Pogledajmo nekoliko primjera emigracijskih krajeva i naselja. Na otoku Braču (bez naselja Bobovišća, Novo Selo i Pražnica, za koja nisu sačuvane matične knjige) broj živorođenih od 1900. do 1910. iznosio je 2462, ili 246,2 prosječno godišnje, a od 1910. do 1931. bio je 1319, ili 62,8 prosječno godišnje (Derado i Čizmić, 1982). Naselje Baška na otoku Krku: 1900. - 1909. bilo je 665 živorođenih (prosječno godišnje 66,5), 1910. - 1919. g. 570 (57), 1920. - 1929. g. 530 (53), 1930 - 1939. g. 360 (36) (Chudy, 1960). Na otoku Korčuli u prvom desetljeću 20. stoljeća broj rođenih smanjen je za 15\% (Kalogjera, 1969) itd. U svim navedenim primjerima došlo je do velikog smanjenja rađanja. Nema dvojbe da je to uvelike posljedica iseljavanja, premda su ratne nedaće, demografska tranzicija i drugi čimbenici tome pridonijeli.

Dugoročni (odgođeni) učinci iseljavanja došli su do izražaja i nakon Drugoga svjetskog rata sve do danas. Od 1950. do 1990. stopa prirodne promjene smanjena je s 12,5 na $0,5 \%$ (25 puta), s jasnom tendencijom prema nultoj prirodnoj promjeni. Godine 1991. dolazi do negativne prirodne promjene, tj. nastupa biološka (prirodna) depopulacija. Tri su glavna čimbenika u to vrijeme djelovala na pojavu prirodne depopulacije: 1) ratna agresija na Hrvatsku 1991./1992., 2) priljev manje brojnih naraštaja u fertilnu dob i 3) nastavak iseljavanja u inozemstvo (Wertheimer-Baletić, 1997). Godine 2001. stopa prirodne promjene iznosila je -1,9\%o (Statistički ljetopis Republike Hrvatske 2009.). Zbog smanjujuće rodnosti (1960. g. 18,4\%o, a 2001. g. 9,2\%o), a manjim dijelom i zbog blago rastuće smrtnosti (za iste godine: 10,0\%o i $11,2 \%$ ), produbljuje se (bio)reprodukcijska depresija u Republici Hrvatskoj 
(»škare se otvaraju«). Hrvatska je 1950. imala vitalni indeks (broj živorođenih na 100 umrlih) 201,9, godine 1990. iznosio je 104,1, godine 2001. bio je 82,7 , a 2011. godine 80,7.

Stanovništvo Hrvatske nalazi se u posttranzicijskoj etapi (niske stacionarnosti), u kojoj stopa prirodne promjene (prirasta) poprima negativne vrijednosti. Valja istaknuti da nijedna europska zemlja nije imala tako ubrzan proces demografske tranzicije (Gelo, 1987). Etapa demografske tranzicije počela je u Hrvatskoj potkraj 19. stoljeća, tridesetih godina 20. stoljeća ulazi u središnju podetapu te završava početkom osamdesetih (Wertheimer-Baletić, 1999). Proces tranzicije trajao je dakle razmjerno kratko, oko osamdeset, devedeset godina. To je svojevrstan paradoks jer Hrvatska nije na takvu stupnju razvijenosti da bi posttranzicijsko (stacionarno) stanovništvo bilo normalan izraz društveno-gospodarskih prilika. Zapravo je riječ o »svojevrsnoj kvaziposttranziciji, induciranoj posttranziciji, uvjetovanoj specifičnim čimbenicima« (Wertheimer-Baletić, 1992: 241). Očigledno su demografske promjene osjetno ispred općerazvojnih. Objašnjenje je vrlo jednostavno. $\mathrm{Na}$ suvremenu demografsku sliku Hrvatske snažno su utjecali vanjski čimbenici iz prošlih razdoblja (inače ih teorija demografske tranzicije zanemaruje) kao što su stalno i jako iseljavanje te gubici u ratovima. Oni su uzdrmali i znatno ubrzali »normalnu« demografsku dinamiku. Već smo ustvrdili da je u tome uloga migracijskih gubitaka bila dominantna; taj je čimbenik odgovoran za gotovo dvije trećine svih populacijskih gubitaka Hrvatske od 1900. do 2001.

\section{Demografsko starenje}

Iseljavanjem mlađih osoba stvaraju se tzv. krnji naraštaji u dobnom sastavu (brojčano slabi), a, kako je već istaknuto, nastaje dugoročni (odgođeni) učinak zbog odljeva (bio)reproduktivnog potencijala. Tako okrnjeni naraštaj roditelja utječe u emigracijskim krajevima na smanjenje broja rođenih, što, uz djelovanje ostalih čimbenika, rezultira starenjem stanovništva, odnosno dovodi do povećanja udjela osoba u starijoj dobi (60 i više ili 65 i više godina). ${ }^{29}$ Dakle promjene $\mathrm{u}$ dobnom sastavu stanovništva Hrvatske sadržavaju dva usporedna globalna demografska procesa: smanjivanje udjela mladih uz istovremeno povećavanje udjela starog stanovništva.

Starenje ukupnog stanovništva u Hrvatskoj je počelo početkom šezdesetih godina 20. stoljeća. Prema popisu iz 1961., bilo je 7,4\% stanovnika u dobi

${ }_{29}$ Zbog sve duljega životnog vijeka u razvijenim je zemljama pomaknuta (statistička) granica između zrele i stare skupine; starim se smatra stanovništvo u dobi od 65 i više godina. Sve se više tome priklanja i dokumentacija Ujedinjenih naroda. 
65 i više godina (Statistički ljetopis Republike Hrvatske 1992.). ${ }^{30}$ No u međupopisnom razdoblju 1961. - 1971., osim povećanja udjela starih u ukupnom stanovništvu (starih je popisano 10,3\%), zabilježeno je i osjetno smanjenje udjela stanovnika u dobi $0-14$ godina (od $27,2 \%$ na $23,5 \%$ ), što je također relevantan pokazatelj demografskog starenja. Proces starenja otad se razmahao poprimajući iz popisa u popis sve nepovoljnija obilježja. Usporedba podataka popisa 1981. i 2011. pokazuje da stanovništvo Hrvatske obilježavaju vrlo brzo starenje i visoki stupanj ostarjelosti. Indeks promjene 1981. - 2011. pokazuje smanjenje broja mladih (do 34 godine), s posebno jakim smanjenjem najmlađih skupina, a s druge strane povećanje broja starih stanovnika, posebice najstarijih dobnih skupina (parcijalno starenje). Indeks promjene broja stanovnika Hrvatske 1981 - 2011. prema pojedinim (funkcionalnim) dobnim skupinama jest sljedeći: 0-14 72,1; 0-19 73,5; 15-39 86,8; 40-64 114,9; 15-64 99,5; 60 i više 162,9; 65 i više 154,2 i 75 i više 207,0.

Visoki porast udjela staračkog stanovništva, posebice najstarijeg dijela toga kontingenta, pokazuje da se Hrvatska približila stanju u razvijenim europskim zemljama, u kojima (barem u većini njih) znatno brže raste udio osoba u starijoj dobnoj skupini staračkoga kontingenta (Nejašmić, 2003) ${ }^{31} \mathrm{I}$ drugi analitički pokazatelji sastava prema dobi potvrđuju predočene nalaze. Prosječna životna dob (starost) stanovništva Hrvatske stalno raste. Godine 1961. bila je 32,5 godina, 1981. godine 35,4 (izračunato prema Statistički ljetopis Republike Hrvatske 1992.), da bi u 2011. dosegnula visokih 41,7 godina (izračunato prema Popis stanovništva, kućanstava i stanova 2011. godine). ${ }^{32}$ Indeks starosti (broj starih 65 i više godina na 100 mladih 0 - 14) 1981. iznosio je 54,4, godine 2001. bio je 91,9, a 2011. godine 116,3. Dakle u Hrvatskoj je osjetno više starih nego mladih. Za razumijevanje procesa starenja vrlo je znakovita usporedba dječje baze $(0-4)$ i osoba starih 75 i više godina; 2001. te su dobne skupine bile praktično izjednačene, a 2011. starih je $62 \%$ više nego djece (212.709 prema 344.230). Na djelu je sve izrazitija inverzija dobne piramide.

Sudeći po predočenim analitičkim pokazateljima, stanovništvo Hrvatske obilježava izrazito duboka starost, najnepovoljniji tip dobnog sastava prema uobičajenoj klasifikaciji. ${ }^{33}$ Očigledno je da do punog izražaja dola-

30 Kada udio osoba starih 65 i više godina dosegne osam posto, smatra se da je stanovništvo neke zemlje ili područja počelo starjeti (Wertheimer-Baletić, 1999).

31 U demografskoj literaturi uglavnom prevladava podjela staračkoga kontingenta na: a) mlađe staračko stanovništvo (65 - 75 godina), b) srednje staračko stanovništvo (75 - 85 godina) i c) vrlo staro stanovništvo (85 i više godina) (Myers, 1994).

32 Kao npr. u Finskoj $(41,6)$ i Švedskoj (41,1) (Statistics Finland, 2011; Statistics Sweden, 2011).

33 Tip sastava prema dobnom sastavu; kombinirana klasifikacija (prema veličini indeksa 
zi demografski momentum (demografska inercija), koji određuje predvidljive promjene dobne strukture u budućnosti (Keyfitz, 1971). Hrvatska se tako našla, i zbog stoljetne negativne migracijske bilance, u društvu europskih zemalja s najstarijom populacijom (Eurostat 2011). S gledišta dobrobiti pojedinca starenje (produljenje ljudskog vijeka) blagodat je i pobjeda ljudske zajednice. No demografsko starenje nedvojbeno je proces koji nepovoljno djeluje na demografska kretanja, općedruštvene prilike i gospodarski razvoj (Stipetić, 1994; Peterson, 1999).

\section{ZAKLJUČAK}

U razmatranom razdoblju, 1900. - 2001., s prostora današnje Republike Hrvatske neprekidno se odvijalo snažno iseljavanje; iselilo se oko 2,3 milijuna stanovnika. Iseljavanje s vremenom nije slabjelo, već traje i danas; to je od posebne važnosti s gledišta demografskih posljedica jer se događa u uvjetima smanjene rodnosti, depopulacije i starenja stanovništva. Najjače prekomorsko iseljavanje početkom 20. stoljeća zbivalo se u okolnostima vrlo visoke rodnosti, pa je time dijelom ublažen odljev »ljudskoga kapitala«. Ipak, u tome je bitnu ulogu odigralo doseljavanje, koje je nadomjestilo polovinu ukupnoga iseljenoga kontingenta. Zapravo, doseljavanje je odgodilo hrvatski »demografski slom« za pola stoljeća. Gubitak nastao stoljetnom vanjskom migracijom (»bilančni manjak«) usisao je 33,4\% prosječnog broja stanovnika, ili 52\% ukupne prirodne promjene (prirasta). Malo je zemalja koje su imale toliki populacijski gubitak u vanjskoj migraciji.

Iseljavanje je, odnosno negativna migracijska bilanca, glavni čimbenik (puno jači od ratnih gubitaka i epidemija) demografskih gubitaka, kao i sporog rasta broja stanovnika Hrvatske u 20. stoljeću. U hipotetičnoj »zatvorenoj populaciji« (dakle bez vanjske migracije) Hrvatska bi 2001. imala najmanje 6,22 milijuna stanovnika, ili 40,1\% više od popisanog broja. Vanjska je migracija prostornom selektivnošću svojih ulaznih i izlaznih tokova također uvelike utjecala na diferencirani regionalni demografski razvoj Hrvatske.

Dugoročni (odgođeni) učinci iseljavanja također su došli do punog izražaja. Iseljavanjem najvitalnijih dobnih skupina došlo je do sužavanja fertilnih kohorti, a posljedično do smanjenja rađanja i povećanja stope smrtnosti. Početkom devedesetih zabilježena je negativna stopa prirodne promjene.

starosti; kontingenti $60^{+}$i 0 - 19): a) mladost $(\leq 22,9)$, b) na pragu starenja $(23,0-34,9)$, c) starenje $(35,0-44,9)$, d) starost $(45,0-54,9)$, e) duboka starost $(55,0-99,9)$ i f) izrazito duboka starost (100,0 i više) (Nejašmić, 2005). 
Na biološku (prirodnu) depopulaciju djelovalo je više čimbenika, no na prvome je mjestu neprekidno i snažno iseljavanje (bilo je više nego dvostruko jače od doseljavanja). To je jedan od glavnih čimbenika zbog kojeg je Hrvatska imala ubrzani proces demografske tranzicije. Iseljavanje mladih dobnih skupina (ujedno i potencijalnih roditelja) ima, uz depopulaciju, također bitnu ulogu u starenju stanovništva, dominantnome demografskom procesu u Hrvatskoj.

Zaključno možemo ustvrditi da se nastavlja circulus viciosus iseljavanja (negativne migracijske bilance), sve izrazitije inverzije dobne »piramide $i$ krajnje nepovoljnih promjena u sastavnicama prirodnoga kretanja. To će pak zakonitošću demografske inercije, i to negativnog momentuma, utjecati na daljnje pogoršanje dobnog sastava (starenje) i smanjenje ukupnog broja stanovnika Hrvatske.

\section{LITERATURA}

Antić, Lj. (1985). Hrvatsko iseljeništvo - osnovne značajke, Zbornik Trećeg programa Radio Zagreba, 12: 71-78.

Bade, K. (1997). From Emigration to Immigration: the German Experience in the Nineenth and Twentieth Centuries, u: K. Bade. i M. Weiner (ur.). Migration Past, Migration Future: Germany and the United States. Providence - Oxford: Bergham Books.

Bićanić, R. (1940). Agrarna prenapučenost. Zagreb: Gospodarska sloga.

Bogić, G. (1922). Grippe i encephalitis lethargica u Jugoslaviji 1918-1921, Glasnik Ministarstva narodnog zdravlja, vanredni broj, 3-42.

Breznik, D. (1975). Unutrašnje migracije, Jugoslovenski pregled, 19 (5): 169-176.

Chudy, B. (1960). Baška: prilog poznavanju depopulacijskih otočnih naselja, Geografski glasnik, 22: 79-92.

Čizmić, I. (1976). Doseljavanje, struktura i položaj naših iseljenika u prekomorskim zemljama. Zagreb: Centar za istraživanje migracija (Teme o iseljeništvu, 5).

Derado, K. i Čizmić, I. (1982). Iseljenici otoka Brača. Zagreb: SIZ za kulturu općine Brač (Brački zbornik, 13).

Gelo, J. (1987). Demografske promjene u Hrvatskoj od 1780. do 1981. godine. Zagreb: Globus.

Gelo, J. (2004). Kretanje broja rezidencijalnog (boravećeg) stanovništva Hrvatske u 20. stoljeću, Društvena istraživanja, 13 (4-5): 653-673.

Gelo, J., Akrap, A. i Čipin, I. (2005). Temeljne značajke demografskog razvoja Hrvatske: (bilanca 20. stoljeća). Zagreb: Ministarstvo obitelji, branitelja i međugeneracijske solidarnosti.

Heršak, E. (1993). Panoptikum migracija: Hrvati, hrvatski prostor, Europa, Migracijske teme, 9 (3-4): 227-302. 
Hranilović, N. (1987). Iseljenička politika i služba u Jugoslaviji između dva rata, Migracijske teme, 3 (3-4): 325-334.

Holjevac, V. (1967). Hrvati izvan domovine. Zagreb: Matica hrvatska.

Horvat, V. (1940). Migracije Hrvata, Liječnički vjesnik, 11: 565-571.

Horvat, V. (1942). Suvremene nutarnje seobe i kretanja Hrvata-posljedice dinamike društvenih procesa. Zagreb: HDT.

Jones, H. (1990). Population Geography. London: Paul Chapman.

Kalogjera, A. (1969). Otok Korčula. Prilog poznavanju socijalno-geografskih obilježja, Radovi Geografskog instituta u Zagrebu, 8: 68-118.

Keyfitz, N. (1971). On the momentum of population growth, Demography, 8 (1): 222-234.

Lajić, I. (1992). Stanovništvo dalmatinskih otoka: povijesne i suvremene značajke depopulacije. Zagreb: Consilium - Institut za migracije i narodnosti.

Lajić, I. (1995). Demografski razvitak Hrvatske u razdoblju od 1991. do 1994, Revija za sociologiju, 26 (1-2): 55-64.

Lajić, I. i Mišetić, R. (2006). Otočni logaritam - aktualno stanje i suvremeni demografski procesi na jadranskim otocima. Zagreb: Institut za migracije i narodnosti - Ministarstvo mora, turizma, prometa i razvitka.

Lakatoš, J. (1914). Narodna statistika. Zagreb: Vlastita naklada.

Lorković, M. (1939). Narod i zemlja Hrvata. Zagreb: Matica hrvatska.

Makale, M. (1912). Zadnji popis pučanstva u Dalmaciji. Beč: Adria.

Maticka, M. (1990). Agrarna reforma i kolonizacija u Hrvatskoj od 1945. do 1948. Zagreb: Školska knjiga - Stvarnost.

Mirošević, F. (1988). Iseljavanje iz Dalmacije u razdoblju od 1921. do 1929., Radovi Zavoda za hrvatsku povijest, 21 (1): 107-119.

Myers, G. C. (1994). Population Growth and Age Structure: Implications and Policy responses, u: European Population Conference, Proceedings, vol. 1. New York: United Nations, 24-33.

Nejašmić, I. (1980). Migracija kao faktor demografskih promjena u Pazinštini. Zagreb: Centar za istraživanje migracija (Teme o iseljeništvu, 9).

Nejašmić, I. (1991). Depopulacija u Hrvatskoj - korijeni, stanje, izgledi. Zagreb: Globus Institut za migracije i narodnosti.

Nejašmić, I. (1995). Hrvatski građani na radu u inozemstou i članovi obitelji koji s njima borave: usporedna analiza statističkih podataka 1971., 1981. i 1991. godine. Zagreb: Institut za migracije i narodnosti.

Nejašmić, I. (2003). Značajke biološkog (demografskog) sastava stanovništva Hrvatske, Hrvatski geografski glasnik, 65 (2): 29-54.

Nejašmić, I. (2005). Demogeografija: stanovništvo u prostornim odnosima i procesima. Zagreb: Školska knjiga.

Nejašmić, I. (2008). Stanovništvo Hrvatske: demogeografske studije i analize. Zagreb: Hrvatsko geografsko društvo.

Nejašmić, I. (2013). Demografsko starenje na hrvatskim otocima, Migracijske i etničke teme, 29 (2): 141-168.

Nejašmić, I. i Mišetić, R. (2004). Buduće kretanje broja stanovnika Hrvatske: projekcija 2001.-2031., Društvena istraživanja, 13 (4-5): 751-776. 
Pavličević, D. (1984). Agrarni odnosi u banskoj Hrvatskoj (1848.-1903.), Naše teme, 28 (11): 2409-2424.

Pirc, B. (1929). Zarazne bolesti u Jugoslaviji od 1918-1928 god., Glasnik Centralnog higijenskog zavoda, 8: 245-348.

Pokos, N. (1999). Procjena broja iseljenih stanovnika Republike Hrvatske od popisa stanovništva 1991. do 30. lipnja 1988. godine, Društvena istraživanja, 8 (5-6): 725-734.

Peterson, P. G. (1999). Gray Dawn: How the Coming Age Wave Will Transform America and the World. New York: Times Books - Random House.

Radetić, E. (1944). Istra pod Italijom 1918-1943. Zagreb: Vlastita naklada.

Rajaković, Z. (1957). Migraciona kretanja stanovništva NR Hrvatske prema podacima popisa stanovništva iz godine 1948. i 1953., Ekonomski pregled, 8 (1-2): 94-113.

Rogers, A. (1984). Migration, Urbanisation and Spatial Population. Boulder: Westview Press.

Salins, P. (1997). Assimilation, American Style. New York: Basic Books.

Stalker, P. (2000). Workers Without Frontiers: the Impact of Globalization on International Migration. Boulder: Lynne Rienner Publishers.

Stevanović, R. i Breznik, D. (1986). Unutrašnje migracije, Jugoslovenski pregled, 30 (12): 577-586.

Stipetić, V. (1954). Agrarna reforma i kolonizacija u FNRJ godine 1945-1948, Rad JAZU, 300: 431-471.

Stipetić, V. (1994). Ekonomski problemi koje donosi starenje stanovništva, Ekonomija, 1 (1-3): 113-117.

Šidak, J., Gross, M., Karaman, I. i Šepić, D. (1968). Povijest hrvatskog naroda g. 1860-1914. Zagreb: Školska knjiga.

Wertheimer-Baletić, A. (1969). Regionalne demografske implikacije zapošljavanja u inozemstvu, Ekonomski pregled, 20 (7-8): 703-724.

Wertheimer-Baletić, A. (1992). Demografske promjene i globalni demografski procesi u Hrvatskoj u poslijeratnom razdoblju, Encyclopaedia moderna, 13 (2): 238-251.

Wertheimer-Baletić, A. (1997). Demoreprodukcijski procesi u Hrvatskoj, u: F. Vojnović, M. Križić i R. Tadić (ur.). Nacionalni program demografskog razvitka. Zagreb: Ministarstvo razvitka i obnove, 55-75.

Wertheimer-Baletić, A. (1999). Stanovništvo i razvoj. Zagreb: Mate.

Woods, R. (1982). Theoretical Population Geography. London: Longman.

Zlatković-Winter, J. (1993). Imigracije u Hrvatskoj: skica povijesnog toka, Migracijske teme, 9 (3-4): 303-323.

Žerjavić, V. (1989). Gubici stanovništva Jugoslavije u drugom svjetskom ratu. Zagreb: Jugoslavensko viktimološko društvo.

Žerjavić, V. (1997). Koliko je osoba iselilo iz područja pripojenih Hrvatskoj i Sloveniji nakon kapitulacije Italije i Drugog svjetskog rata, Casopis za suvremenu povijest, 29 (1): 147-153.

Živić, D. i Pokos, N. (2004). Demografski gubitci tijekom Domovinskog rata kao odrednica depopulacije Hrvatske (1991-2001), Društvena istraživanja, 13 (4-5): 727-750.

Žuljić, S. (1989). Narodnosna struktura Jugoslavije i tokovi promjena. Zagreb: Ekonomski institut. 
Županov, J. (1997). Gubitak ljudskih resursa i kulturnog kapitala zbog iseljavanja, u: F. Vojnović, M. Križić i R. Tadić (ur.). Nacionalni program demografskog razvitka Zagreb: Ministarstvo razvitka i obnove, 103-112.

\section{IZVORI}

Migracija stanovništva Republike Hrvatske u 2002., Priopćenje 7.1.2., Državni zavod za statistiku, Zagreb, 2003.

Popis žiteljstva od 31. XII. 1910. u Hrvatskoj i Slavoniji (demografske prilike i zgrade za stanovanje), sastavio Kr. zemaljski statistički ured u Zagrebu, Zagreb, 1914.

Popis stanovništva, domaćinstava i stanova 1981., Radnici u inozemstou, Dokumentacija 501, Republički zavod za statistiku, Zagreb, 1982.

Popis stanovništva, domaćinstava $i$ stanova 1981., Stanovništvo po naseljima, općinama $i$ zajednicama općina, Dokumentacija 553, Tabela 1.2.15, Republički zavod za statistiku, Zagreb, 1984.

Popis stanovništva, kućanstava i stanova 2011. godine, Državni zavod za statistiku, Zagreb http://www.dzs.hr/Hrv/censuses/census2011/.

Statistički godišnjak kraljevina Hrvatske i Slavonije, knjiga I (1901-1905), Kraljevski zemaljski statistički ured, Zagreb, 1913.

Statistički godišnjak kraljevina Hrvatske i Slavonije, knjiga II (1906-1910), Kraljevski zemaljski statistički ured, Zagreb, 1917.

Statistički godišnjak za 1929, Opšta državna statistika kraljevine Jugoslavije, Beograd, 1932.

Statistički ljetopis Republike Hrvatske 1992., Državni zavod za statistiku, Zagreb.

Statistički ljetopis Republike Hrvatske 2009., Državni zavod za statistiku, Zagreb.

Statistics Finland, 2011, http://www. tilastokeskus.fi/väestö/ http://www.tilastokeskus. fi/tup/suoluk/suoluk_vaesto_en.html (22. 1. 2013).

Statistics Sweden, 2011, http://www.scb.se / http://www.scb.se/en_/Table presentation (22. 01. 2013.).

Eurostat 2011, European Commision, /tgm/table Action/, http://epp.eurostat.ec.europa. eu (22. 01. 2013.). 


\title{
Emigration from Croatia from 1900 to 2001: Demographic Consequences of the Centuries-Old Process
}

\author{
Ivo Nejašmić
}

\author{
SUMMARY
}

In the period between 1900 and 2001, about 2.3 million people emigrated from the present-day territory of the Republic of Croatia. Immigration mitigated the outflow of "human capital"; it replaced almost a half of the total emigrated contingent. The migration "balance deficit" took $33.4 \%$ of the average population number, or $52 \%$ of the total natural change (increase). Only a few countries have had such a significant population loss due to emigration. Total Croatian population losses in the observed period amount to about 1.89 million people, and some categories have the following share: negative emigration balance $63.3 \%$, war losses $32.7 \%$ and epidemics $4.0 \%$. If there were no emigration (i.e. in a hypothetical "closed population"), Croatia would have at least 6.22 million people in 2001 or $40.1 \%$ more than the registered number. The long-term (delayed) effects of emigration have also come to the fore. The emigration of the most vital age groups has led to the narrowing of fertile cohorts, and consequently to a decrease in birth rates and increased mortality. In the early 1990s, negative natural change was recorded. Several factors affected biological (natural) depopulation, but emigration took the first place. Continuous and strong emigration, and negative net migration respectively, is one of the main reasons underlying the fact that Croatia belongs to the group of ten European countries with the oldest population. After the $19^{\text {th }}$ century, in which the population of Croatia doubled, and the $20^{\text {th }}$ century, when the country saw weak growth $(40.4 \%)$, the $21^{\text {st }}$ century will be marked by depopulation. A highly negative migration balance from the analyzed centennial period has an important role among many factors having impact on such Croatian demographic perspective.

KEY WORDS: emigration, migration balance, population losses, demographic consequences of emigration, Croatia 